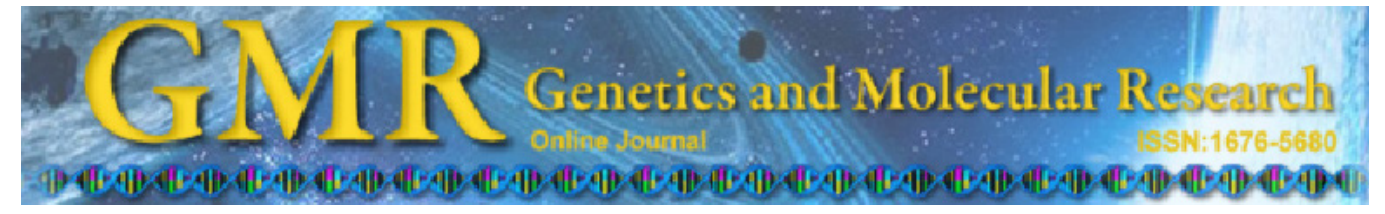

\title{
New insights into the prolactin-RsaI (PRL-RsaI) locus in Chinese Holstein cows and its effect on milk performance traits
}

\author{
C.H. Dong ${ }^{1}$, X.M. Song ${ }^{2}$, L. Zhang ${ }^{2}$, J.F. Jiang ${ }^{2}$, J.P. Zhou ${ }^{1}$ and Y.Q. Jiang ${ }^{2}$ \\ ${ }^{1}$ Agricultural Science and Engineering Department, \\ Shandong Agriculture and Engineering University, Jinan, Shandong, China \\ ${ }^{2}$ Institute of Animal Husbandry and Veterinary Science, \\ Zhejiang Academy of Agricultural Sciences, Hangzhou, China \\ Corresponding authors: X.M. Song / Y.Q. Jiang \\ E-mail: songxuemei@yeah.net / jyq61@sohu.com \\ Genet. Mol. Res. 12 (4): 5766-5773 (2013) \\ Received February 22, 2013 \\ Accepted August 27, 2013 \\ Published November 22, 2013 \\ DOI http://dx.doi.org/10.4238/2013.November.22.3
}

\begin{abstract}
Prolactin (PRL) plays central roles in mammals' reproduction, gland development, milk secretion, and the expression of milk protein genes. In dairy cattle, the $P R L$ gene is a potential quantitative trait locus and genetic marker related to milk performance traits. Here, a total of 586 randomly selected Chinese Holstein cows were genotyped for locus PRL-RsaI. One haplotype block containing eight SNPs was identified in the region from intron 3 to intron 4 of the $P R L$ gene in Chinese Holstein cows. One tag SNP $(7545 \mathrm{G} \rightarrow \mathrm{A})$ was selected to represent the haplotype block defined by the genotypic data. The cows with genotype AA of this tag SNP had a higher milk yield at 305 days $(8457 \pm 938 \mathrm{~kg})$ than the cows with GA $(7537 \pm 1278 \mathrm{~kg}$; $\mathrm{P}<0.01)$ or GG $(7757 \pm 1174 \mathrm{~kg} ; \mathrm{P}<0.05)$. This suggests that the haplotype block examined in this study contains important markers for milk production traits in Chinese Holstein cows.
\end{abstract}

Key words: $P R L-R s a \mathrm{I}$ locus; Milk performance traits; Chinese Holstein cow 


\section{INTRODUCTION}

Prolactin (PRL) is a polypeptide hormone with multiple functions that plays central roles in reproduction, mammary gland development, initiation of milk secretion, and the maintenance of lactation in mammals. In addition to being a classical pituitary hormone, PRL is also primarily responsible for the synthesis of many milk components, including milk proteins, lactose, and lipids (Le Provost et al., 1994; Dahl, 2008). Therefore, the bovine $P R L$ gene is considered to be an excellent candidate for linkage analysis of quantitative trait loci that affect milk performance traits in dairy cattle.

Several DNA polymorphisms have been found within the bovine $P R L$ gene. Lewin et al. (1992) found a silent $A \rightarrow G$ mutation in codon 103 of exon 4, resulting in a polymorphic $R s a \mathrm{I}$ restriction site. They also showed that this $P R L-R s a \mathrm{I}$ locus affected milk production traits, including milk yield, milk fat yield and milk protein yield. A subsequent study reported that Holstein-Friesian cows with the GG genotype at $P R L-R s a \mathrm{I}$ had a significantly higher milk yield and produced milk with a higher fat percentage than those with the AA genotype (Chung et al., 1996). Until now, $P R L-R s a \mathrm{I}$ has been a popular genetic marker for the genetic characterization of cattle populations. However, allele frequencies of the polymorphic $P R L-R s a \mathrm{I}$ and the influence of these alleles on milk performance traits are not consistent across the diverse range of beef, dairy cattle, and water buffalo breeds (Brym et al., 2005).

In the present study, we described the mutation pattern of polymorphism in $P R L-R s a \mathrm{I}$ through polymerase chain reaction single-strand conformation polymorphism (PCR-SSCP) and DNA sequencing. Furthermore, we compared the allele frequencies of different commercial cattle breeds and investigated the relationship between $P R L-R s a \mathrm{I}$ polymorphism and milk production traits in Chinese Holstein cows.

\section{MATERIAL AND METHODS}

\section{Experimental animals}

A total of 586 randomly selected Chinese Holstein cows were genotyped for the $P R L$ $R s a \mathrm{I}$ locus. The cows were kept in the same commercial herd in Qingdao (Shandong, China) to minimize variation in environmental factors, which could interfere with the phenotypic effects of this locus. Only cows for which data were obtained from their first three lactations and of their milk performance traits [corrected milk yield in 305 days of lactation $(\mathrm{kg})$, fat percentage, and protein percentage] were included in the statistical analysis.

\section{Primers, PCR amplification, genotyping, sequencing, and analysis of mutations}

The PRL-RsaI genotypes were analyzed using the PCR-SSCP method. A 249-bp fragment (GenBank accession No. AC_0001591) was amplified using primer pair P1 (P1 forward: 5'-CACATGTTACCAAATCCACTGAA-3' and P1 reverse: 5'-CTCACCTGGCCAAATATC ATCTC-3'), which were designed to include intron 3, exon 4, and intron 4 of the bovine $P R L$ sequence (GenBank accession No. AC_000180).

PCR was performed with a $25-\mu \mathrm{L}$ reaction containing $10 \mathrm{pM}$ of each primer, $200 \mu \mathrm{M}$ of each dNTP, $2.5 \mu \mathrm{L}$ 10X PCR buffer (including $1.5 \mathrm{mM} \mathrm{MgCl}_{2}$ ), $1 \mathrm{U}$ Taq DNA polymerase 
(Fermentas, Thermo, USA), and $50 \mathrm{ng}$ genomic DNA as template. The cycling protocol was 4 min at $95^{\circ} \mathrm{C}$, followed by 35 cycles of $94^{\circ} \mathrm{C}$ for $30 \mathrm{~s}$, annealing at $60^{\circ} \mathrm{C}$ for $30 \mathrm{~s}$, and extension at $72^{\circ} \mathrm{C}$ for $30 \mathrm{~s}$; this was followed by a final extension step at $72^{\circ} \mathrm{C}$ for $10 \mathrm{~min}$, and then the reaction was held at $4^{\circ} \mathrm{C}$. Reactions were performed using a Mastercycler 5333 thermocycler (Eppendorf AG, Hamburg, Germany).

At least three to five representative DNA samples for each SSCP electrophoretic pattern were purified and used for sequencing. Purified 773-bp PCR products from each SSCP variant were amplified and sequenced with primer pair P2 (P2 forward: 5'-TCTCTCCCCAGACAA GCA-3' and P2 reverse: 5'-TACCCAGGAAGAGGCAAG-3'). Then, the fragments were sequenced in both directions to identify the absolute location of the mutations detected by PCRSSCP. The fragments covered the whole exon 4 and parts of introns 3 and 4, based on the bovine PRL sequence available in GenBank (AC_000180), and were analyzed with Mutation Surveyor $^{\mathrm{TM}}$ (SoftGenetics, LLC, State College, PA, USA).

\section{Statistical analysis}

Genotype and allele frequencies were tested for deviation from Hardy-Weinberg equilibrium (HWE) by using a $\chi^{2}$ test (Devlin and Risch, 1995; Nielsen et al., 1998). Allele frequencies and polymorphism information content (PIC) were derived using POPGENE Version 1.31 (Molecular Biology and Biotechnology Centre, University of Alberta: Edmonton, Canada) (Yeh and Boyle, 1997).

HaploView version 4.2 was used to determine the $\mathrm{r}^{2}$ and D' values of linkage disequilibrium (LD) between pairwise combinations of eight SNPs within the $P R L$ gene (Barrett et al., 2005). Pairs of SNPs are in "strong LD" if the one-sided upper $95 \%$ confidence boundary of D' is $>0.98$ (which is consistent with there having been no historical recombination) and the lower boundary is $>0.7$ (Gabriel et al., 2002).

The association between each $P R L$ haplotype and milk performance traits was quantified using a single marker linear model by the restricted maximum likelihood method in SPSS Version 13.0 (SPSS Inc., Chicago, IL, USA). Haplotype and milk performance traits were included as fixed effects in the model:

$$
\mathrm{Y}_{\mathrm{ij}}=\mu_{\mathrm{i}}+\mathrm{M}_{\mathrm{j}}+\mathrm{e}_{\mathrm{ij}}
$$

where $Y_{i j}$ is the observed value of milk performance trait; $\mu_{i}$ is the least square mean; $M_{j}$ is the fixed effect of the $j^{\text {th }}$ genotype ( 3 levels); and $e_{i j}$ is the random residual effect of each observation.

\section{RESULTS}

\section{PCR-SSCP analysis and genetic polymorphism of locus PRL-RsaI among Chinese Holstein cows}

A 249-bp fragment of the bovine PRL gene (AC_000180, NM_173953) was amplified with primer pair P1 from a DNA sample from each Chinese Holstein cow. These PCR products were subsequently denatured and subjected to polyacrylamide gel electrophoresis to detect sequence variation. Three PCR-SSCP band patterns were found (Figure 1). Eight 
polymorphisms were found in the $P R L$ gene: $\mathrm{T} \rightarrow \mathrm{C}$ in position 7256 (where position 1 is the first nucleotide of AC_000180) located in intron 3; $\mathrm{T} \rightarrow \mathrm{G}$ in position 7348 located in intron 3; a $\mathrm{T}$ insertion in position 7439 located in intron 3; $\mathrm{T} \rightarrow \mathrm{C}$ in position 7454 located in intron 3; $\mathrm{C} \rightarrow \mathrm{G}$ in position 7524 located in exon 4 ; $\mathrm{G} \rightarrow \mathrm{A}$ in position 7545 located in exon 4 (locus $P R L-R s a \mathrm{I}) ; \mathrm{T} \rightarrow \mathrm{C}$ in position 7657 located in intron 4; and $\mathrm{T} \rightarrow \mathrm{C}$ in position 7680 located in intron 4 (Figure 2).

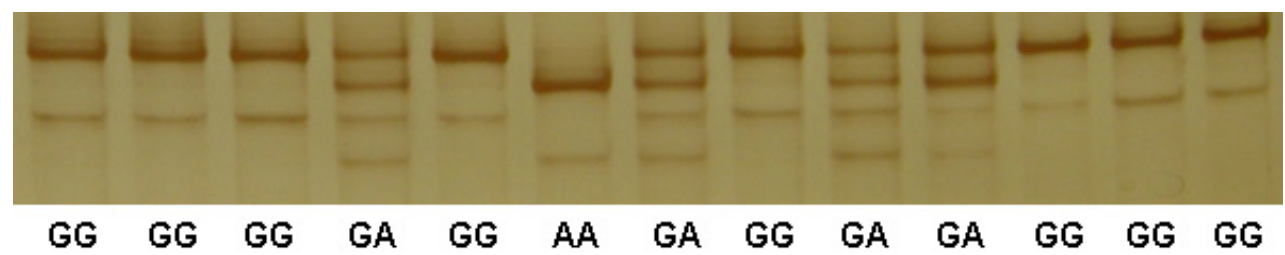

Figure 1. SSCP polymorphism of the $P R L-R s a \mathrm{I}$ locus PCR product. Three SSCP patterns are visible: GG, GA and AA.
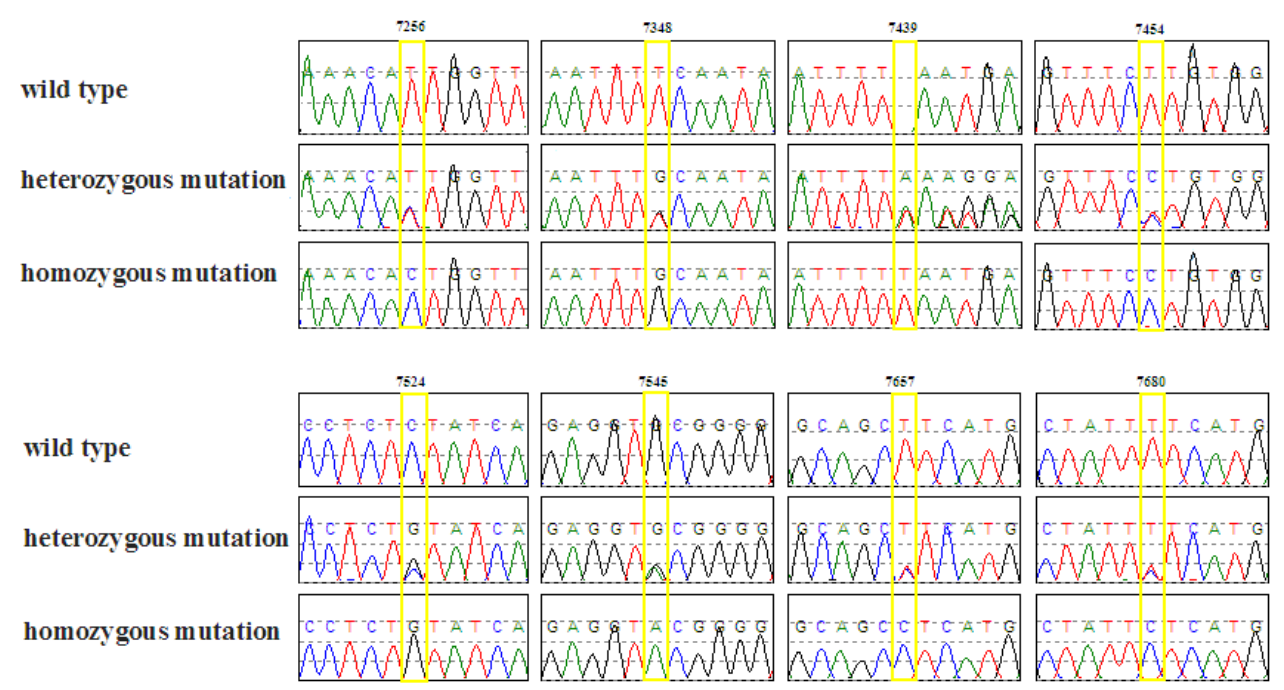

Figure 2. Results of direct sequencing of a 773-bp fragment of the $P R L$ gene by Mutation Surveyor, showing eight polymorphic sites at positions: 7256, 7348, 7439, 7454, 7524L, 7545 R, 7657, 7680.

\section{Intra- $P R L$ linkage disequilibrium}

The haplotype block was defined using the D' value of the lower $95 \%$ confidence interval in the analysis. Results are shown in Figure 3, where the red diamonds indicate strong LD between two SNPs (D'>0.8) with statistical significance (LOD score > 2.0) (Barrett et al., 2005). The $\mathrm{r}^{2}$ value among the eight SNPs in the haplotype block was 1 , which suggested that the eight SNPs were completely linked with each other. One tag SNP $(7545 \mathrm{G} \rightarrow \mathrm{A})$ was selected to represent the genetic variation in the haplotype block. 


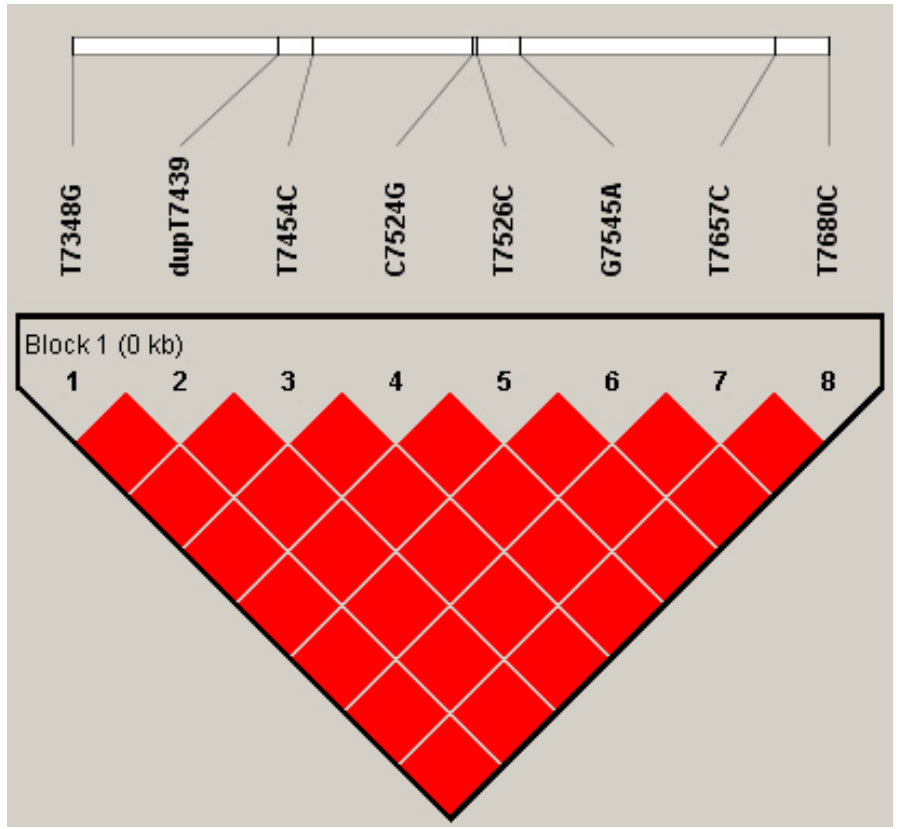

Figure 3. Linkage disequilibrium pattern among 8 SNPs at the $P R L$ gene by the Haploview analysis.

\section{Genetic polymorphism in the $P R L$ gene of Chinese Holstein cows}

Allele frequencies, genotype frequencies, and PIC of the haplotype block were analyzed. Allele G was the predominant allele at Tag SNP locus 7545. The PIC values of the haplotype block indicated that the eight SNPs should be considered as only slightly polymorphic (Table 1). Furthermore, the haplotype frequencies of $P R L$ in Chinese Holstein cows were in accordance with HWE $(\mathrm{P}<0.01)$.

Table 1. Frequencies of genotypes and alleles of the Chinese Holstein cow PRL-RsaI locus.

\begin{tabular}{lccccc}
\hline Polymorphism & Genotypes & Genotypic frequencies & Alleles & Allelic frequencies & PIC \\
\hline Tag g.7545G $>$ A & GG (445) & 0.7594 & G & 0.8754 & 0.1944 \\
& GA (136) & 0.2321 & & & \\
& AA (5) & 0.1180 & A & 0.1246 & \\
\hline
\end{tabular}

\section{Least square mean and standard error for milk performance traits of locus $P R L$ - RsaI polymorphism in Chinese Holstein cows}

The least square mean and standard error of each milk performance trait was calculated using a general linear model, for each allele of locus $P R L-R s a \mathrm{I}$ in the Chinese Holstein cows (Table 2). Genotypes were found to vary significantly with respect to the milk performance traits $(\mathrm{P}<0.05$; Table 2$)$. Cows with allele AA at locus 7545 had a higher milk yield 
at 305 days $(8457 \pm 938 \mathrm{~kg})$ in comparison to those with the GA allele $(7537 \pm 1278 \mathrm{~kg}$; $\mathrm{P}<$ $0.01)$ and GG allele $(7757 \pm 1174 \mathrm{~kg} ; \mathrm{P}<0.05$; Table 2$)$. However, the percentage of fat and protein in milk did not differ between the genotypes $(\mathrm{P}>0.05)$.

Table 2. Genotype means, standard errors, $P$ values, and estimates of additive and dominance effects for milk performance traits of different $P R L-R s a I$ locus genotypes in Chinese Holstein cows.

\begin{tabular}{lccccc}
\hline & SNP & \multicolumn{3}{c}{ Genotype means \pm SD } & Overall P value $^{1}$ \\
\cline { 3 - 5 } & g. 7545 G $>\mathrm{A}$ & $\mathrm{GG}$ & $\mathrm{GA}$ & $\mathrm{AA}$ & \\
\hline Milk yield at 305 days (kg) & & $7757 \pm 1174^{\mathrm{a}}$ & $7537 \pm 1278$ & $8457 \pm 938^{\mathrm{A}}$ & 0.013 \\
Fat percentage (\%) & & $4.169 \pm 0.804$ & $4.117 \pm 0.772$ & $3.807 \pm 0.582$ & 0.282 \\
Protein percentage (\%) & & $2.991 \pm 0.261$ & $3.015 \pm 0.242$ & $3.061 \pm 0.209$ & 0.450 \\
\hline
\end{tabular}

Values for genotype effects are given as least square means $( \pm \mathrm{SD})$ of milk production traits. Within lines, means with the same superscript differ at $\mathrm{P}<0.05$ (lowercase letter) or $\mathrm{P}<0.01$ (uppercase letter).

\section{DISCUSSION}

The PRL gene influences water numerous biological processes: electrolyte balance, growth, development, endocrinology, metabolism, regulation of diverse functions within the brain, maintenance of maternal behavior, reproduction, and immunoregulation (Bole-Feysot et al., 1998). The non-synonymous amino acid variation in bovine PRL associated with the alleles of $P R L-R s a \mathrm{I}$, tag SNP $(7545 \mathrm{G} \rightarrow \mathrm{A})$ in this study, is well known. The objectives of this study were to study gene frequencies of the PRL-RsaI locus and their effects in Chinese Holstein cows.

More polymorphisms were found in this study than in previous studies of a variety of commercial cattle breeds. In this study, seven polymorphisms were found in the $P R L$ gene, in addition to the SNP that defines the PRL-RsaI locus. Furthermore, all eight SNPs were assessed as being completely linked with each other (Figure 3 ). We only amplified a 773-bp fragment, which included locus $P R L-R s a \mathrm{I}$, due to the limited length of PCR product that could be sequenced directly. It is possible that the haplotype block studied may contain other mutations, and further mutations and haplotype blocks may exist elsewhere in the $P R L$ gene.

The allele frequencies of $P R L-R s a \mathrm{I}$ found in this study were 0.8754 for $\mathrm{G}$ and 0.1246 for A, which are similar to those reported previously (Malveiro et al., 2001; Brym et al., 2005; Boleckova et al., 2012). In previous studies, allele G ranged from 0.4 to 0.95 in different cattle breeds. Allele $\mathrm{G}$ has also been reported to be the high allele with allele frequency $>0.60$ in Indian native cattle (Bos indicus) breeds and cattle breeds from other countries (Brym et al., 2005; Sodhi et al., 2011). Conversely, research on a large number of buffalo (Bubalus bubalis) breeds native to India has shown that the allele A is significantly more common $(0.3-0.62)$. This suggests that a significant difference may exist in the frequency of allele $\mathrm{G}$ between populations and between breeds (Sodhi et al., 2011).

As with PRL-RsaI allele frequencies, the phenotypic effects of these alleles also differ among the cattle (Bos taurus) studied and buffalo (Bubalus bubalis) breeds. In this study, Chinese Holstein cows with AA at locus 7545 had a higher milk yield at 305 days ( $8457 \pm 938$ $\mathrm{kg})$ than cows with GA $(7537 \pm 1278 \mathrm{~kg}$; P $<0.01)$ or GG $(7757 \pm 1174 \mathrm{~kg}$; P $<0.05)$. This is consistent with data from Russian Red Pied cattle, where the AA genotype had a positive effect on milk yield (Alipanah et al., 2007). Conversely, genotype AA has a negative effect on 
milk yield in Montbéliarde cows, and Holstein cows with genotype AG have been shown to have the highest milk yield of that breed (Brym et al., 2005; Ghasemi et al., 2009). Moreover, it has been proposed that gene effects between Russian Black Pied cattle and Russian Red Pied cattle were different (Alipanah et al., 2008). Therefore, the association of this polymorphism with milk production traits had not previously been confirmed.

Since a few new mutations have been identified in the $P R L$ gene (Brym et al., 2005; Lu et al., 2010; Jia et al., 2011), it is necessary to investigate possible linkage between these mutations. Furthermore, other SNPs occurring within PRL should evaluate their influence on milk production traits, and should be used in haplotype association studies across different dairy cattle breeds.

\section{ACKNOWLEDGMENTS}

Research supported by the National Natural Science Foundation of China (\#31001020); the Shandong Province Key Technologies R\&D Program (\#2010GNC10932); the Key Scientific \& Technological Project of the Zhejiang Province (\#2010C12007 and \#2008C02002-1); and the Scientific and Technological Innovation Team of Zhejiang Province (\#2010R50027).

\section{REFERENCES}

Alipanah M, Kalashnikova L and Rodionov G (2007). Association of prolactin gene variants with milk production traits in Russian Red Pied cattle. Iranian J. Biotechnol. 5: 158-161.

Alipanah M, Alexandrovna K and Rodionov GV (2008). Kappa-casein and PRL-Rsa I genotypic frequencies in two Russian cattle breeds. Arch. Zootec. 57: 131-138.

Barrett JC, Fry B, Maller J and Daly MJ (2005). Haploview: analysis and visualization of LD and haplotype maps. Bioinformatics 21: 263-265.

Bole-Feysot C, Goffin V, Edery M, Binart N, et al. (1998). Prolactin (PRL) and its receptor: actions, signal transduction pathways and phenotypes observed in PRL receptor knockout mice. Endocr. Rev. 19: 225-268.

Boleckova J, Matejickova J, Stipkova M, Kyselova J, et al. (2012). The association of five polymorphisms with milk production traits in Czech Fleckvieh cattle. Czech J. Anim. Sci. 57: 45-53.

Brym P, Kaminski S and Wojcik E (2005). Nucleotide sequence polymorphism within exon 4 of the bovine prolactin gene and its associations with milk performance traits. J. Appl. Genet. 46: 179-185.

Chung ER, Rhim TJ and Han SK (1996). Association PCR-RFLP markers of growth hormone and Prolactin genes and production traits in diary cattle. Korean J. Anim. Sci. 38: 321-336.

Dahl GE (2008). Effects of short day photoperiod on prolactin signaling in dry cows: a common mechanism among tissues and environments? J. Anim. Sci. 86: 10-14.

Devlin B and Risch N (1995). A comparison of linkage disequilibrium measures for fine-scale mapping. Genomics 29: 311-322.

Gabriel SB, Schaffner SF, Nguyen H, Moore JM, et al. (2002). The structure of haplotype blocks in the human genome. Science 296: 2225-2229.

Ghasemi N, Zadehrahmani M, Rahimi G, Hassan S, et al. (2009). Associations between prolactin gene polymorphism and milk production in Montbéliarde cows. Int. J. Genet. Mol. Biol. 1: 48-51.

Jia XJ, Wang CF, Yang GW, Huang JM, et al. (2011). Polymorphism of POU1F1 gene and PRL gene and their combined effects on milk performance traits in Chinese Holstein cattle. Yi Chuan 33: 1359-1365.

Le Provost F, Leroux C, Martin P, Gaye P, et al. (1994). Prolactin gene expression in ovine and caprine mammary gland. Neuroendocrinology 60: 305-313.

Lewin HA, Schmitt K, Hubert R, van Eijk MJ, et al. (1992). Close linkage between bovine prolactin and BoLA-DRB3 genes: genetic mapping in cattle by single sperm typing. Genomics 13: 44-48.

Lu A, Hu X, Chen H, Jiang J, et al. (2010). Single nucleotide polymorphisms in bovine PRL gene and their associations with milk production traits in Chinese Holsteins. Mol. Biol. Rep. 37: 547-551. 
Malveiro E, Pereira M, Marques PX, Santos IC, et al. (2001). Polymorphisms at the five exons of the growth hormone gene in the Algarvia goat: possible association with milk traits. Small Rumin. Res. 41: 163-170.

Nielsen DM, Ehm MG and Weir BS (1998). Detecting marker-disease association by testing for Hardy-Weinberg disequilibrium at a marker locus. Am. J. Hum. Genet. 63: 1531-1540.

Sodhi M, Mukesh M, Mishra BP, Parvesh K, et al. (2011). Analysis of genetic variation at the prolactin-RsaI (PRL-RsaI) locus in Indian native cattle breeds (Bos indicus). Biochem. Genet. 49: 39-45.

Yeh FC and Boyle TJB (1997). Population genetic analysis of co-dominant and dominant markers and quantitative traits. Belgian J. Bot. 129: 157. 